\title{
Erken Dönem İslam Hukuk Tarihindeki Hukuk Ekollerinin Oluşumunda Coğrafya, Kültür ve Sosyal Şartların Etkisi
}

Saliha OKUR GÜMRÜKÇÜOĞLU ${ }^{1}$

Özet

İslam fikıh mezhepleri olarak da nitelendirilen İslam hukuk okullarının doğuş ve gelişim seyrine baktığımızda bunların bulundukları bölgenin renklerini taşıdıklarını söylemek mümkündür. Makaleye konu olarak seçtiğimiz ekoller İslam hukuk tarihinde Sünni hukuk ekolü olarak bilinen ve mensubu bakımından günümüze kadar ulaşan Hanefi, Maliki, Şafii ve Hanbeli hukuk ekolleridir. Zikri geçen her bir ekolün neş’et ettiği coğrafyanın ihtiyaç ve şartlarına göre şekillendiğini ifade edebiliriz.

Çalışmada bu okulların ortaya çıkış ve gelişim seyirleri incelenerek, birçok İslam hukuk tarihi ve mezhepler tarihi alanında yazılmış eserlerdeki detaylı bilgileri tekrardan kaçınarak, söz konusu okulların bulundukları coğrafya, kültür ve sosyal şartların mezhebin metodolojik farklılıklarına ve oluş̧urdukları hukuk normlarına etkisinin ne ölçüde olduğu gün yüzüne çıkarılmaya çalışılmıştır.

Anahtar Kelimeler: Fıkıh, mezhep, coğrafya ve kültür, örf

\section{The Effect of Geography, Cultures and Social Conditionson the Formation of Schools in the History of Islamic Law}

\begin{abstract}
Abstact
When we look at the birth and development of Islamic law schools, it is possible to say that they carry the structure of the region. Theese schools we chose as subjects are Hanafi, Shafii, Maliki and Hanbali that known as Sunni law school in the history of Islamic law.It is possibleto say that theeseshoolsare shaped by the needs and conditions of the geography in which they are located.

In this study, we examined that emergence and development of theseschools and avoided repetition of detailed information swhich were written in the History of Islamic Law books. We tried to show that level of effects of schools' culture and geography on the methodologic differences of mazhabsand legal norms.
\end{abstract}

Keywords: Fiqh, mazhab, geography and culture, urf-custom.

\section{Giriş}

Hiç şüphesiz tarihte gerek siyasi gerekse hukuki oluşumları etkileyen birçok faktör bulunmakla birlikte, coğrafya, kültür ve sosyal şartlar zikretmemiz gereken etkenlerin başında gelir. Zira her fikri oluşum, dayandığı felsefi temel dişında neş'et ettiği coğrafya ve örfle şekillenir. Mezhep ya da hukuk ekolü diye tabir edeceğimiz oluşumların bugünün modern insanının zihninde çok da olumlu çağrışımlar oluşturmadığı bilinmektedir. Zira günümüz insanı mezhep dendiğinde genellikle "taassub" ya da "taklid" kelimelerini düşünmektedir. Ancak tarihte önemli yer tutan ve milyonlarca insanı tabii olma konusunda ikna eden söz konusu oluşumları daha detaylı irdelemek, gelişim seyirlerini tahlil etmek şüphesiz dikkate değer bir konudur. Zira tarihte hiçbir ekol ihtiyaçtan vâreste bir şekilde oluşmamıştır.

İslam hukuk tarihindeki ekollerin oluşumu incelendiğinde, gerek ekollerin kendi içerisinde, gerekse diğer ekol arasında farklılık gösteren bir kısım hükmün sebebini

${ }^{1}$ Yrd. Doç. Dr, İstanbul Medeniyet Üniversitesi, Hukuk Fakültesi Hukuk Tarihi Anabilim Dalı,

saliha.ogumrukcuoglu@medeniyet.edu.tr 
Yalova Sosyal Bilimler Dergisi

tahlil ederken iklim ve coğrafi farklılıkları göz ardı etmek mümkün değildir. Zira bir bölgede problem teşkil etmeyen bir mesele, başka bir bölgede pek çok problemin kaynağı olabilmektedir. Böyle durumlarda problemin mahiyetinin ve meydana geliş şeklinin verilecek hükmü de doğrudan etkilemesi kaçınılmaz olur. Öte yandan aynı problemin farklı coğrafyalarda yaşayan fikıh âlimleri tarafından değerlendirilişi de farklı olacaktır. Meseleye çözüm noktasından baktığımızda ise belli bir coğrafi alanı kapsayan problemlerin çözümlerinin, diğer bölge insanlarından ziyade, yine aynı bölge insanı için bir anlam ifade edeceği muhakkaktır. Bununla birlikte coğrafi olarak farklı bölgelerde yaşayan insanlar için söz konusu hüküm ve çözümler pek bir anlam ifade etmeyecektir.

Örf olarak da tanımlayabileceğimiz coğrafya ve kültürün Hz. Peygamber döneminden başlayarak dört halife dönemi ve sonrasında oluşan hukuk ekollerindeki hükümlerin oluşmasinda önemli tesirleri olmuştur ${ }^{2}$. Hz. Peygamber ve hemen sonraki döneme baktığımızda şüphe yok ki yeni fetihlerle genişleyen İslam coğrafyasında sahabeler, Peygamberin hayatında hükme kaynaklık teşkil edecek başlıkların yanında (KitapSünnet-İcma Kıyas) maslahat, örf ve adet gibi yerel uygulamaları da göz ardı etmemişlerdir. $\mathrm{Bu}$ duruma gerek dört halife döneminde gerekse daha sonraki dönemlerde uygulamada rastlamak mümkündür.

Dört halife arasında özellikle Hz. Ömer'in örfe göre verdiği hükümler tarihi kayıtlarda çokça zikredilmektedir. Fethedilen toprakların statüsü, müellefe-i kulübün zekât hissesi ve tek sözle verilen üç talak meselesi bunların başında gelir. Öte yandan kendi devrinde hüküm süren kıtlık yılında hırsızlıktan dolayı el kesme cezasını uygulamaması diğer bir uygulamasına örnek olarak gösterilebilir. Şüphe yok ki Hz. Ömer'in içtihatlarında dönemin şartları ve ihtiyaçları göz önünde bulundurulmuştur. Hz. Ömer dışındaki sahabelerin de kendilerine sorulan sualler karşısında dönemin şartlarını gözeterek fetva verdikleri bilinmektedir.

Hz. Ömer'in uygulamalarına bir örnek de zanaatkârların yanında bırakılmış veya unutulmuş eşyaların zayi olması durumunda zanaatkâra ödetilmemesi uygulamasının kaldırılmasıydı. Zira Hz. Ömer devrine kadar süregelen bu uygulamanın onun zamanında kötü niyetli zanaatkârların çoğalmasıyla değiştiğine ve artık kaçınılması mümkün olan bir sebeple telef olan eşyaya tazmin sorumluluğunun getirildiğine şahit olmaktayız (Şafii, 1968, III: 261).

Sahabe ve tabiin tarafından verilen fetvaların çeşitliliği ve farklılı̆̆ı, gerek peygamberden nakledilen hadis malzemesinin mezhebin ileri gelenlerine ulaşıp ulaşmaması, gerekse muhit ve yerel uygulama farklılıkları sebebiyle Irak ekolü ve Hicaz ekolünü meydana getirmiştir. Söz konusu ekoller rey'i ve hadisi anlama ve değerlendirme açısından farklılık arz ettiğinden, günümüze kadar "Kufe ekolü” veya "Hicaz ekolü” olarak anılagelmiştir.

Medine temelli Hicaz ekolünde gerek ayetlerin gerekse Hz. Peygamberin söz ve uygulamalarının zahiri anlamının yeterli görülerek, akıl yürütme ve yoruma daha az

${ }^{2}$ Geniş bilgi için bkz. Muhammed Y. Faruq1, (1992) "Consideration of 'Urf in the Judgments of the Khulefâ' al Râshidun and the Early Fukahâ" The American Journal of Islamic Social Sciences, Volume 9, number 4, p. 482-498. 
Yalova Sosyal Bilimler Dergisi

başvurulduğu görülmektedir. Buna karş1lık Irak merkezli Kufe ekolünde ise, rey ve içtihadın ağırlık kazandığı, coğrafi farklılık ve ihtiyaçların yanında, nassın ve amaçlanan hedefin üzerine bina edildiği genel maksatların (makasıdü’ş-şeria) öncelenerek içtihad ve akıl yürütmeye dayalı bir hukuki anlayışının gelişmesine zemin hazırladığı söylenebilir. Şüphe yok ki zikri geçen bu temel farklılıklar mezheplerin oluşmasında önemli katkı sağlamıştır.

Öte yandan şekil bakımından birbirine benzeyen ve fakat hüküm açısından birbirinden ayrılan fikhî meseleler literatürde "Furuk" kitaplarında detaylı bir şekilde işlenmiştir. Çoğunlukla hükmün konulmasındaki illet farklılığını konu alan söz konusu eserlerin muhteviyatını teşkil eden meseleler, makale konumuz dışında bırakılmıştır. ${ }^{3}$

\section{Hanefi Ekolü}

Kufe Irak merkezli olan Hanefi mezhebi kronolojik olarak Hz. Peygamber dönemine en yakın mezhep olarak nitelendirilir. Nitekim mezhebin kurucusu Numan b. Sabit h. 80 ile 150 yılları arasında yaşamıştır. Kendisinin zengin bir tüccar olarak hayatını sürdürdüğü, daha sonra ise ilim meclislerine başladığı ifade edilir. Yaşadığı bölgenin ileri gelenlerinden oluşunun ve ticaretle olan meşguliyetinin ileride öncüsü olacağ mezhebin fetvalarına yansıyacak olması anlaşılabilir bir durumdur.

Ebu Hanife'nin yaşadığı dönemde Kufe'de gerek itikadi gerekse siyasi tartışmaların olduğu bilinen bir gerçektir. Hanefi mezhebinin Irak fikhı içerisinde oluşmasının mezhebe doktriner anlamda etki ettiği de muhakkaktır. Kufe şehrinin Hz. Ömer'in döneminden başlayarak önem kazanması, o bölgeye yerleşen Hz. Ali ve Abdullah b. Mesud gibi önemli fakihlerin bulunması Irak fikhının şekillenmesinde önemli katkı sağlamıştır.

Bilindiği üzere İslam hukuk tarihinde ilmi noktada dikkate değer en önemli ayrışma Emeviler döneminde Irak (Kufe) ve Hicaz (Medine) fukahası arasında meydana gelmiştir. $\mathrm{O}$ dönemde üstat farklılığına dayanan bu ayrışmada Hicaz ekolünün imamı Said b. El-Müseyyeb (ö. 94/712), Iraklıların imamı ise İbrahim en-Nehai (ö. 96/714) olarak ifade edilir (Zeydan, 1986: 139-140).

Ekoller arasındaki ilmi ve fikri farklılı̆̆ı aynı mezhep içerisinde de görmek mümkündür. Nitekim Ebu Hanife'nin önde gelen talebelerinden uzun dönem Kadı'lKudatlık (Başkadılık) vazifesini ifa eden Ebu Yusuf'un pek çok konuda hocasından farklı düşündügü kayıtlarda sabittir. Şüphe yok ki bu görüş farklılığına, kadılığı esnasında mahkemede karşılaştığı davaların etkisiyle içtihad farklılı̆̆ sebep olmuştur denilebilir. Mesela hakim istemese bile davalıya yemin teklif edilmesi, sözleşmeleri ve diğer tasarrufları korumak için sefihin ancak hakim kararıyla hacr altına alınabileceği gibi bazı görüşleri zikri geçen vazife esnasında verdiği görüşlere örnek olarak gösterilebilir (Ögüt, 1994, X: 264; Matlub, 1972: 411.).

Ebu Hanife'nin diğer talebesi İmam Muhammed'in ise Ebu Yusuf'dan Kufe fikhını öğrendikten sonra Medine'ye geçip İmam Malik'ten Muvatta'yi dinlediğini biliyoruz.

${ }^{3}$ Konu ile ilgili bkz. Kızılkaya, Necmettin, İslam Hukukunda Farklar, İstanbul 2016. 
Yalova Sosyal Bilimler Dergisi

Daha sonra onun Mekke'de de Süfyan b. Uyeyne'den, Dımaşk'ta Evzai'den, Horosan'da ise Abdullah b. Mübarek'ten ders aldıktan sonra Bağdat'a yerleştiği ifade edilir (Taş, 1994, XXXIX: 38-39). Harun Reşid zamanında Rakka kadılığına getirilmiş, bir müddet sonra Ebu Yusuf'un vefatıyla başkadılık görevi de kendisine tevdi edilmiștir (Kevseri, 1952: 40). İmam Muhammed'in kadılık yaptığı dönemde şüphesiz uygulamaya yönelik tecrübeler sonucunda farklı içtihatlarda bulunduğu bilinmektedir. Öte yandan İmam Muhammed'in mezhebe yaptı̆̆ en büyük katk1, ders esnasında yapılan tartışmaların kaleme alınıp farklı görüş ve meselelerin sonraki nesillere aktarılmasıdır. Zira Ebu Hanife'nin bizzat kaleme aldığı bir fikıh eseri yoktur.

Gerek Okulların kendi aralarındaki görüş farklılıklarına gerekse aynı okulun (mezhebin) mezhep içi görüş farklılıklarına baktığımızda şu tespitleri yapmak mümkündür: Öncelikle Hanefi mezhebi bağlamında Ebu Hanife ile mezhebin önde gelen talebelerinden olan Ebu Yusuf'un veya İmam Muhammed ya da İmam Zufer arasındaki görüş farklılıklarının bir kısmı hiç şüphesiz teori ve pratik arasındaki farklılıklardan ileri gelmektedir. Gerek mezhep imamlarını, gerek aynı mezhepte bulunup İmameyn olarak tabir edilen her iki imamın kendi hocaları dışında başka hocalardan hadis dinlemiş olmaları, ayrıca farklı ülkelerdeki örflere muttali olup yerel ihtiyaçları yerinde gözlemleyip anlamalarının tabii sonucu olarak farklı içtihatlarda bulunmuşlardır. Mezhep içerisindeki görüş farklılıklarının diğer ekollere nazaran Hanefi mezhebi içerisinde daha fazla olduğu bilinmektedir. Nitekim günümüze ulaşan literatürün hacmi bu gerçeği kanıtlar mahiyettedir.

Öte yandan mezhep imamlarına tabi olan yerel halkın bu tabiiyeti körü körüne gerçekleştirmemesi de bizzat zikri geçen ekollerin ileri gelen alimleri tarafindan önemle üzerinde durduğu bir meseledir. Zira kitap ve sünnetin yerine tabi olunan müçtehidin görüşünü koymak, İslam fikhını ayakta tutacak olan içtihad müessesesinin de atıl kalmasına sebep olacaktır. Bu kabilden olarak Ebu Hanife'nin "Söylediğimizi araştırmadan bizim kanaatimizle fetva vermek hiç kimse için helal değildir" ifadesi ile "Bu bizim vardığımız sonuçların en iyisidir. Bu sonuçtan daha iyisini bulan olursa onu kabul ederiz" ifadesi taklit konusundaki görüşlerini anlamak için yeterli bir karinedir (Fullani, ty.: 51).

Coğrafi farklılığın ve kültürün mezhebin hükümlerine etkisini Hanefi alimlerden İbn Abidin'in ifadelerinde bulabiliriz. O'na göre, örfe bağlı pek çok hüküm, zamanla gerek örfün değişmesi gerekse bazı zaruretlerin doğması veya toplumun genel ahlakının bozulması sebebiyle değişiklik gösterir. Böyle olmayıp, şayet daha önce verilen hükümler olduğu gibi değişmeden kalacak olsaydı, bu durum insanlara zorluk verebileceği gibi; İslam'ın temel prensiplerinden olan, mükellefiyetlerin hafifletilmesi (tahfif), kolaylaştırma (teysir) gibi külli kaidelere de aykırı bir durum oluşturabilirdi. (İbn Abidin, ty., II: 125) Nitekim Örf ve adetlerin hükümlere tesiri Mecelle'nin 39. maddesinde "Ezmanın tağayyürü ile ahkâmın teğayyürü inkâr olunamaz." şeklinde ifadesini bulmuştur. ${ }^{4}$

\footnotetext{
${ }^{4}$ Mecelle'deki örf ile ilgili diğer maddeler şöyledir: "Adetin delaletiyle manayı hakiki terk olunur." (md. 40), "Adet ancak muttarid ve galip oldukça muteber olur." (md. 41), "Örfen maruf olan şey, şart kılınmış gibidir." (md. 43), "Beyne't-tuccar maruf olan şey beyinlerinde meşrut gibidir." (md.44), "Örf ile tayin nass ile tayin gibidir." (md. 45).
} 
Yalova Sosyal Bilimler Dergisi

Ayrıca yine önemli Hanefi âlimler arasında sayılan İbn Ebi'l-İzz el-Hanefi'ye göre de bir mezhebe körü körüne bağlanmak yerine, delile kuvvetli olan görüşe ittiba etmek esastır. Dolayısıyla zamanında bazı âlimlerin iddia ettiği gibi içtihad kapısı kapanmış değil, bilakis Hz. Peygamber'den günümüze kadar yapılması gerekli bir ameliyedir (İnanır, 2015: 158). ${ }^{5}$

Kufe-Irak bölgesinde yayılmaya başlayıp, mezhebin önde gelen talebeleri sayesinde pek çok bölgede hüsn-ü kabul gören Hanefi mezhebi içerisindeki bazı fetvalara bakmakta fayda mülahaza etmekteyiz. Zira mezhebin yayıldı̆̆ bölgelerdeki örfi uygulamaların fetvalara ne ölçüde yansıdığını görmek dikkate değer bir konudur.

Hanefi fakihlerinden Ebu Bekir el-İskaf'a sofralarının etrafinda yemek almak için ayakta durana yemek verilmesi durumu sorulduğunda, o bu durumun dilenciye ikram edilmesinin caiz olmadığı hadisi kapsamında değerlendirilemeyeceğini; o bölgede yaşayan insanların teamülüne itibar edileceğini bildirmiştir. Başka bir ifade ile bu husus kıyasa göre caiz olmamasına rağmen, o bölgede yerleşmiş bir uygulama ise istihsanen caiz olacağını ifade eder (Güllük, 2003: 54). Zikri geçen fetvadan da anlaşıldığı üzere, toplumda örf olarak yerleşmiş bazı davranışlarda fikhi açıdan istihsânen sıkıntı görülmemiştir.

Bir başka örnek Hanefi mezhebinde menkul olan eşyanın vakfedilmesi hususudur. Hanefilerde cari olan usule göre menkul malların vakfedilmesi caiz değildir.(Bedir, 2014, 199) Ancak İmam Muhammed bu duruma ihtiyaç ve örf gereği fetva vermiş̧tir. Nitekim İslam hukukunda menkul malların vakfi gibi Selem Akdi ve İstisna Akdi de örfe göre istihsanen geçerli sayılan hukuki işlemler arasındadır (Zeydan, 1982: 201). Yine aynı kabilden olmak üzere Hanefi imamlardan Ebu Yusuf'a göre de paranın vakfedilmesi caiz değildir. Ancak İmam Züfer'e göre bu da mümkündür. Para vakıflarının cevazıyla ilgili fetva birden fazla âlimin fetvasının birleştirilerek ulaşılan bir sonuçtur. Zira Ebu's-Suud Efendinin konu ile ilgili fetvası, menkul malların vakfedilebileceğini içeren hükmünün İmam Muhammed'in kanaatinden; bir kimsenin kendisi için vakf yapabilmesinin geçerli oluşu hususunun Ebu Yusuf'un görüşünden, para vakfina izin verilen kanaatin de Ebu Yusuf'un görüşünden yararlanılarak (telfik yoluyla) ortaya çıkmıştır (Rıza, 1974: 133).

Mezhep içinde verilen fetvaların bölgelere göre değiştiğine bir örnek de ibadetler konusu içerisinde yer alan ve abdestte mest etme konusu ile ilgili fetvadır. Ayağa giyilen ve abdestte üzerine mest edebilme özelliği taşıyan giysi bölgelere göre değişiklik arz ettiğinden, konu ile ilgili hüküm de değişmektedir. Zira Farsça olarak "pîşbend" olarak ifade edilen bir meste de mest etmek caiz görülmüştür. Bu çeşit mestin ön tarafı iki parçalı ve delinmiş olup bir bağcık ile bağlanmaktadır. Şüphesiz bu şekilde meste cevaz verilmesinin sebebi o bölgede ayağa giyilen ve yolculuk yapılan bir giysi olması sebebiyledir (Kadıhan, 1865, I: 43).

Bölgesel farklılığın hükümlere etkisine bir örnek de ziraat ile ilgilidir. Irak bölgesinde iklim sebebiyle ekin zamanı değişkenlik göstermektedir. Bu sebeple aynı yıl birden

\footnotetext{
${ }^{5}$ Daha geniş bilgi için bkz. İnanır, Ahmet, (2013), “İbnEbi'l-İzz'in 'İttiba' Adli Risalesi Bağlamında Ebu Hanife ve Hanefi Mezhebi Örneğinde Taklide Dair Görüşleri” Gaziosmanpaşa Üniversitesi İlahiyat Fakültesi Dergisi, 2013, c. I, sy. 2, s. 225-260.
} 
Yalova Sosyal Bilimler Dergisi

fazla ürün alınabilmektedir. Bu sebeple Müzaraa akdinde ${ }^{6}$ süre tayini şarttır. Ancak kara ikliminin hüküm sürdüğü Orta Asya bölgesinde ekin zamanında değişkenlik olmadığı ve senede tek ürün alındığı için süre tayini şart olmamaktadır (Tetik, 2006: 139; Kasani,1997, VIII: 273).

Yine Hanefi alimlerden İbn Ebi'l-İzz, zekat konusunda, ayette zikredilen sınıflardan her birine zekattan pay verilmesi zaruretini ifade eden Hanefi dışındaki mezhep görüşleri karşısında Hanefi ekolünü tercih ederken; aynı ekolün durgun suya az bir necaset bulaştı̆̆ında kirlendiği hükmünün diğer mezhep görüşlerine kıyasla çok katı bir tutum olduğunu ifade eder ve bu durumun insanların hayatlarını zorlaştırdığını belirtir (İnanır, 2015: 159).

Hanefi mezhebi içerisindeki fetvalardan da anlaşıldığı üzere, bölgenin ihtiyaçları ve coğrafi farklılıklar verilen hükümlerde etkisini göstermektedir. Mezhep içerisindeki söz konusu fetvaların istihsan, maslahat ve örf delili çerçevesinde verildiğini söylemek mümkündür.

\section{Maliki Ekolü}

Tarihi sırada ikinci ekol olan Maliki ekolü, hicri ikinci asırda Hicaz fikhının gelişmesiyle ortaya çıkmıştır. Maliki ekolünün önde gelen ismi Malik b. Enes (d. 93/179-ö. 717/795) dönemin önemli ilim merkezlerinden biri olan Medine'de ilim tahsil etmiştir. İmam Malik'in hac dışında Medine'den ayrılmadığı ve vefatının da Medine'de olduğu bilinmektedir.

Mezhep öncelikle Hicaz bölgesinde yayıldıktan sonra, Mısır'da da taraftar bulmuştur. Hatta İmam Malik hayattayken onun talebeleri sayesinde Misır'da bir maliki muhiti oluştuğu ifade edilmektedir. Talebeleri arasında İbn Kasım ve İbnVehb ve Eşheb elKaysi'nin bu ekole önemli katkıları olduğu bilinmektedir (Kaya, 2003, XXVII: 522).

Maliki mezhebinin yayılmasında hac yolu üzerinde olmasının tesiri büyüktür. Zira dünyanın her yerinden gelen Müslümanlar, mensup oldukları dinin peygamberinin yaşadığı yeri görmek ve kabrini ziyaret etmek için Medine'ye gelmişlerdir. Medine'yi ziyaret eden pek çok insan Hz. Peygamberin mescidinde hadis okuyan İmam Maliki dinlemiş, pek çoğu da onun talebesi olmak için Medine'de kalmıştır.

$\mathrm{Bu}$ ekolü diğer ekollerden ayıran en önemli özellik şüphesiz uzun yıllarını $\mathrm{Hz}$. Peygamberle geçirmiş olan Medine halkının uygulamalarının İmam Malik nezdindeki değeridir. Başka bir ifade ile İmam Malik füru fikhını temellendirirken Kuran ve Sünnetten sonra Medinelilerin Amelini (Medinelilerin İcma'1) ${ }^{7}$ üçüncü sıraya koyarak diğer sünni mezheplerden farkını ortaya koymuş bulunmaktadır.

\footnotetext{
${ }^{6}$ Müzaraa akdi: "Tohum ekmek ve mahsulü belli oranda paylaşmak üzere arazi sahibiyle emek sahibi arasında yapılan ziraî ortaklık sözleşmesini ifade eder. Müzâraaya günümüzde Trakya ve Marmara'da yarıcılık, Orta Anadolu'da ortakçılık, Doğu Anadolu'da marabacılık denilmektedir.” Bkz. Kayapınar, Hüseyin, (2006), “Müzaraa”, DİA, İstanbul, XXXII, s. 234-236.

7 Pek çok Maliki fikıh kitabında Medinelilerin İ́cma'ı olarak tabir edilen bu delil hakkında İmam Şafii, söz konusu icmanın Medine dışındaki alimler tarafından ihtilafa konu olduğunu ve bu sebeple İmam Malik'in gerçekleştiğini söylediği icmanın hakikatte vuku bulmadığını ifade eder. Şafii, (1968), el-Umm, c. VII, s. 235.
} 
Yalova Sosyal Bilimler Dergisi

Fetvaların coğrafi bölgeye göre öncelendiği yorumunu da yapabileceğimiz amel-i ehl-i medine kıstasını, Medine'de yaşamış Müslümanların fikhi uygulamalarına verilen öncelik olarak anlamak mümkündür. Nitekim İmam Malik'e göre Medine'de yaşayanlar ayet ve hadislerin geliş sebeplerine ve yaşanan hadiselere daha iyi vakıf olduklarından dini bir konuda yapılacak fikhi yorumları da tercihe şayan konumdadır. Öte yandan o haber-i vahidle Medinelilerin uygulamaları çeliştiğinde Medinelerinin uygulamalarının tercih edilmesi gerektiğini vurgular (Sıbâi,1978: 430-431). İmam Malik'in Leys b. Sa'd'a gönderdiği mektupta bu fikrini açıça ifade ettiği görülmektedir (Aktepe, 2008: 213).

İmam Malik'in Medinelilerin amelini kimi zaman sahabe görüşüne de tercih ettiğini görmekteyiz. Başka bir ifade ile sahabe görüşü Medine halkı tarafindan yerleşik bir örfe ve kurala dönüşmüşse, bunu delil olarak kabul etmektedir. Nitekim Hz. Ömer' in "Eman alarak İslam ülkesine giren bir yabanciyı öldüren kimsenin boynunu vuracağına" dair sözünü naklettikten sonra, bu görüşün üzerinde icma bulunmadığı ve uygulamanın da bu yönde olmadığı gerekçesiyle söz konusu görüşü reddeder (Malik b. Enes, 1994, II: 320).

Maliki ekolünün genel olarak mezhep içi görüş tercihlerine baktığımızda şu tespiti yapmak mümkündür: Iraklı fakihler ile Mağribli fakihler arasında ihtilafa düşüldüğünde genel olarak Mağriblilerin görüşüne göre amel edilmesi esastır. Öte yandan Mısırlılar ve Medinelilerin görüşleri arasında bir farklılık yaşanırsa, o durumda da genellikle Mısırlıların görüşleri öncelenir. Fakat Mağrib ve Medine arasında bir ihtilaf vukuunda ise Medinelilerin görüşlerinin tercih edildiği görülmüştür.

Bölgesel farklılarda belli bölgelerin tercihindeki maksadı incelediğimizde Mısırlıların diğer bölgelere göre tercih sebebi olmasını, şüphesiz ekolün ileri gelen alimlerinin Mısırlı olmalarıyla açıklamak mümkündür. Medinelilerin Mağribe öncelenmesi ise "Ehavân" diye tabir edilen ekolün önde gelen kişilerinin ${ }^{8}$ Medine'den oluşlarıdır. Öte yandan Mağriblilerin Iraklılara öncelenmesi de "Şeyhayn"1n9 Mağribden olmasıyla açıklanır (Y1lmaz, 2008: 37).

Maliki fikhında da diğer ekollerde olduğu gibi bölgelere göre şekillenmiş bazı uygulamalar vardır. Bölgenin örf ve uygulamaları, yaşayan halkın ihtiyaçları doğrultusunda şekillenmiş amelleri mahalli amel olarak isimlendirmek mümkündür.

İbn Haldun da bunu bir icma olarak değil, Medinelilerin nesilden nesile aktardığı uygulamaları olarak anlamak gerekir der. Zira İcma'1 sadece Medinelilere has kılmak mümkün değildir. Bkz. İbn Haldun, Ebu Zeyd Veliyüddin Abdurrahman b. Muhammed, (1982), Mukaddimetü'l-Allame İbn Haldun, Beyrut, s. 447.

Ayrıca İmam Malik'in usulünde kullandığı fikhi ifadeler bazen yöresel bir ittifakı, bazen de böyle bir ittifakı aşan bir fikir birliğini çağrıştırır. Bu ittifakları anlatırken kullandığı "el-emr" veya "essünne" kelimelerinin aynı anlamda olup olmadığı ise açık değildir. Bununla birlikte kaynağının $\mathrm{Hz}$. Peygamber'e kadar geri gittiğini tespit ettiği uygulama için "sünnet", diğer ameller için "amel" veya "emr" kelimelerini de kullandığı söylenebilir. Yine de İmam Malik'in söz konusu ayrıma sonuna kadar riayet ettiğini söylemek zordur. Bkz. Aybakan, (2003), Fıkıh İlminin Oluşum Sürecinde İcma, İstanbul, s. 96-97.

${ }^{8}$ Mutraf b. Abdullah ve Abdülmelik b, Mâcişûn.

${ }^{9}$ Ebu Zeyd elKayrevâni ve İbnü'l-Kâbisi. 
Yalova Sosyal Bilimler Dergisi

Maliki fikhının fetvalarına baktığımızda daha ziyade yaşanmış olaylara verildiği fetvalarla şekillendiği anlaşılmaktadır. İmam Malik' in kendisine yöneltilen farazi meselelere cevap vermediği ve bu şekilde sualleri olanların Irak'a (Kufeye) gitmesini tavsiye ettiği ifade edilir.

Maliki mezhebinden örnek vereceğimiz fetvalar ise şu şekildedir:

Hz. Peygamberin uygulamasında bugün için "Etiket üzerinden satı̧̧" olarak ifade edilen malın görülmeden ve ne olduğu bilinmeden alıcıya satılması yasaklanmıştır ${ }^{10}$. Ancak İmam Malik'in söz konusu satış için “ Bu satış insanlar arasında yapılan bir alışveriş ve herhangi bir mahzuru olmayan bir ticaret şeklidir." demek suretiyle söz konusu satışa cevaz verdiği anlaşılmaktadır. İfadede yer alan insanların da Medineliler olması muhtemel gözükmektedir (Malik b. Enes, 1994, III: 250).

Nitekim bugünün ticaretinde de s1k sık bu satış şekli karşımıza çıkmaktadır. Gerek büyük firmaların tonlarca yaptıkları satış ve nakliyelerde, gerekse sanal ortamdaki satışlarda, alıcının malı teslim aldığında malda bulunabilecek ayıp ve kusurdan ötürü iade şartı saklı kalmak kaydıyla etiket üzerinden satış zaruri olarak bugün de yapılagelmektedir. Nitekim Maliki fakihlerinden Kadı Abdülvehhab söz konusu satışın cevazını "Allah alışverişi helal, faizi haram kıldı" (Bakara 2/274) ve "Birbirinizin malını haksızlıkla yemeyin. Ancak karşılıklı rıza ile yapılan ticaret müstesna" (Nisa 4/29) ayetlerini ileri sürerek açıklamıştır. O Zikri geçen alışverişi içine bakılmadan satılan kabuklu yemişlere benzeterek ispata çalışır (Kadı Abdülvehhab, 1999, II: 521522).

Bir başka fetvada İmam Malik, Hz. Peygamber'in olgunlaşmayan meyvelerin dalında satılmaması gerektiğini ifade eden hadisi ile ilgili olarak, kendi bölgelerinde yetişen kavun, karpuz, salatalık ve havuç gibi ürünlerin dalında iken satılabileceğine dair hüküm vermektedir. Bu hükümde İmam Malik'in insanların ihtiyac1 ve maslahat prensibiyle hareket ettiği söylenebilir (Malik b. Enes, 1994, III: 195).

Maliki fakihlerinden İbn Rüşd'ün oğlunu kurban etmeyi adayan kimseye ne gerekeceği hususundaki soruya verdiği cevap ise şöyledir: Konu ile ilgili İmam Malik bir deve, Ebu Hanife bir koyun gerekeceğini, Ebu Yusuf ve İmam Şafii adanan günah bir adak olduğu için hiçbir şey gerekmeyeceğini ifade ederken, İbn Rüşd bu konuda, söz konusu uygulamanın Hz. İbrahim örfüne ve o döneme ait bir uygulama olduğu için böyle bir durumun Müslümanları kapsamadığı ve konuyu tartışmanın gereksiz olduğu sonucuna varmıştır. Başka bir ifade ile böyle bir adağın önceki şeriatlerin uygulamaları bağlamında değerlendirip hükmen hiçbir şey gerekmediğini ifade etmiş olmaktadır (İbnRüşd, 1997, I: 333-334).

Bilindiği üzere şahitlikte asl olan adalet vasfidır. Başka bir ifade ile bu vasfa sahip olmayanların davada şahit olarak dinlenilmesi geçerli olmaz. Maliki fakihi Karafi bulunan bölgede adalet vasfına sahip kimse bulunmazsa, o vakit kişiler içerisinden en

\footnotetext{
10 Mülâmese: Cahiliye devrinde dürülü bir kumaş veya elbisenin açıp görmeden yalnızca elle yoklanarak ve içinde ne olduğu bilinmeyerek yapılan satışa verilen isim (İbnRüşd, (1991), Bidayetü'l-Müçtehid, (trc. Ahmet Meylani) İstanbul, III, s. 182; İbnRüşd, (1997), Bidayetü'lMüçtehid ve Nihâyetü'l-Muktesıd, Beyrut, c. III, s. 202)
} 
Yalova Sosyal Bilimler Dergisi

iyi olanı şahit olarak dinlemekten başka bir yol kalmamaktadır. Şüphesiz bu durumu meşakkatin uzaklaştırılıp maslahatın öne alınması şeklinde de değerlendirmek mümkündür (Karafi, 1993: 391).

\section{3. Şafii Ekolï}

İmam Şafii (d. 150/767-ö.204/820) Gazze'de dünyaya gelmiş ve küçük yaşta ilimle meşgul olmaya başlamıştır. İlk tahsilini Mekke'de yaptıktan sonra, Huzeyl kabilesine gidip orada bir müddet yaşayarak Arap şifahi kültürünü, örf ve adetlerinin yanı sıra Arap dilini ve edebiyatını da öğrenmiştir. Medine'de İmam Malik ile tanışana kadar pek çok isimden ders aldığı, Medine'ye gittiğinde Muvatta'yı ezbere bildiği bilgisi de kaynaklarda ifade edilmektedir. İmam Malik'in vefatına kadar ders halkasına devam eden İmam Şafii, ilmi yeteneği ve azmi sayesinde Muvatta'nın ravileri arasında da yer almıştır. İmam Malik'in vefatından sonra tekrar Medine'ye oradan da bir davet üzerine Yemen'e gittiği kaydedilmektedir. (Aybakan, 2011: 22-30)

Yemen'de geçici olarak bir kamu görevinde bulunan İmam Şafii, dönemin siyasi çalkantıları içerisinde yönetime ayaklanma çıkaranların içinde telakki edilerek Rakka'ya sürgüne gönderildi. O sirada Ebu Hanife'nin talebesi olan Muhammed b. Hasan eş-Şeybani ile tanışıp ondan Kufe fikhını öğrendi. Daha sonra Mekke'de ve bir müddet Bağdat'ta bulunduktan sonra Misır'a giderek, orada vefat etti. (Aybakan 2010, XXXIIX: 224)

İmam Şafii Ebu Hanife'den farklı olarak kendi görüşlerinin bizzat kaleme aldığı telif eserlerle günümüze ulaşmasını sağlamıştır. Fıkıh ve usulle ilgili eserleri dışında talebelerinin de eserleri Şafii fikhının yayılmasında önemli rol üstlenmiştir. İmam Şafii'nin eserleri arasında Er-Risale, el-Umm (el-Mebsut), el-Hucce bunlardan bazılarıdır. El-Hucce adlı eserinin kavl-i kadim denilen eski görüşlerini yansıtan bir eser olduğu bilinmektedir. (Ebu Zehre, 1948: 156 vd)

İmam Şafii'nin Mısır'a geldikten sonra Irak'da verdiği fetvaların bir kısmını değiştirdiği bilinmektedir. Nitekim Bağdat'ta kendisine sorulan sorulara verdiği fetvalar ile Mısır'dakiler birbirinden farklıdır. Bu sebeple Şafii fikhını iki dönemde incelemek mümkündür. Eski ve yeni (mezheb-i kadîm, mezheb-i cedîd) olarak nitelendirilen bu dönemlerdeki fikhi görüşler eserlere de yansımış ve İmam Şafii, Bağdat'ta sahip olduğu bir kısım görüşten vazgeçip, yeni fetvalar üretmiştir. Bunda kendine ulaşan hadislerin sayısının artmasının, ilmi açıdan belli bir birikim ve olgunluğa erişmesinin yanında, hiç şüphesiz Mısır kültürünün ve yerleşik örfün de etkisini göz ardı etmek mümkün değildir.

İmam Şafii'nin kavl-i kadim diye nitelendirilen eski görüşlerinin tamamen hocası İmam Malik'in görüşleri olduğunu savunan tarihçiler mevcuttur. (Safedi, 1974, II: 12) Ancak söz konusu etkileşim mümkün olmakla birlikte, İmam Şafii'nin tüm görüşlerinin hocasıyla aynı istikamette olduğunu söylemek çok iddialı bir kanaati ifade eder. İmam Şafii'nin bir takım görüşlerinin hocasıyla örtüşmesi tabii bir durumdur. Zira İmam Malik, kendisinin uzun süre ders halkasına devam ettiği hocalarından biridir. 
Yalova Sosyal Bilimler Dergisi

Öte yandan İmam Şafii'nin birbiriyle tenakuz halinde görünen görüşlerini değerlendirirken, bu durumu iki mezhep veya iki görüş olarak okumaktan ziyade, ilmi birikiminin sonucu değiştirdiği görüşleri olarak okumak gerekir. Zira kendisi de Mısır'a gittikten sonra verdiği fetvalar sonucu artık bu görüşlerinin esas alınması gerektiğini, eski görüşlerinin nakledilmemesini istemiştir (Ebu Zehre, ty., II: 272). Ayrıca Bağdat'taki görüşlerinin daha ziyade ehl-i rey taraftarlarına bir reddiye hüviyeti taşırken, Mısır'daki görüşlerinin gerek ehl-i rey gerekse ehl-i hadis literatürünü kapsayıcı daha eklektik bir yapı arz ettiğini söylemek mümkündür (Aybakan, 2010: 225; a.mlf, 2011: $100 \mathrm{vd}$.)

İmam Şafii'nin Mısır'a geldiğinde Bağdat'taki bütün görüşlerinden vazgeçtiği gibi bir iddia da şüphesiz gerçeği yansıtmayacaktır. Zira İmam Şafii Mısır'a geldikten sonra yeni eserlerini yazarken Irak'taki görüşlerinden değiştirmeden aynen aldıklarının yanında, farklı kanaate sahip olduğu meseleleri de yeniden kaleme aldığı görülmektedir (Ebu Zehre, ty.: 271). Kendisine ulaşan sahih bir rivayet veya farklı bir örf karşısında önceden verdiği fetvayı tekrar değerlendirip görüşünden vazgeçtiğini açıklıkla ifade ettiği görülmektedir. İmam'ın daha önce ifade ettiği kanaatinde 1 srarcı olmayıp taassup göstermemesini ve bu durumu "Sahih hadis bulunca benim mezhebim odur." (Fullani, ty.: 147-148) cümlesiyle ifade etmesini, bir bakıma mezhep taassubunun eleştirisi olarak anlamak mümkündür.

İmam Şafii hüküm istinbat etmedeki usulünü, Kur'an, Sünnet, Sahabe Kavli olarak açıklarken, hayvanların diyeti ile alakalı bir mevzuda, bölgesel farklılık temeline dayanan bir fetvadaki sahabe kavlini kıyasa tercih ettiğini gösteren örneği şu şekilde zikredebiliriz:

İmam Şafii kara hayvanlarının fidyesinin ayetle belirtilerek misliyle ödenmesi gerektiğini vurguladıktan sonra (Maide 5/95), uçan hayvanların fidyesi hususuna gelince Mekke güvercini konusunda kıyasa göre değil sahabe kavline göre hareket ettiği görülür. Şöyle ki: "Kim Mekke güvercinini öldürürse bir koyun kurban etmesi gerekir.” Burada Mekke güvercinin koyuna denk olmadığı kesin olmakla birlikte, sahabenin sözüne muhalefet eden başka bir sahabe kavli bulunmadığından İmam Şafii'nin bu görüşü tercih ettiğini söylemek mümkündür (Şafii, 1968, II: 165-166).

Öte yandan o hocası İmamı Malik'in öncelediği Medineliler amelini sübjektif bir delil olarak değerlendirerek kaynak değerini eleştirir. Bütün Medine'de yaşayan Medinelilerin herhangi feri bir meselede icma edip aynı kanaate sahip olmalarının neredeyse imkansız olduğu savunur. Hadd-i zatında İmam Malik' in Medinelilerin icma ettiği konuların aslında fukahanın pek çoğunun ihtilaf ettiği konular olduğunu ifade ederek, zikredilen icmanın fiiliyatta gerçekleşmediğini ifade eder (Şafii, 1968, VII: 188, 245).

Ebu Hanife'nin ihtiyatla yaklaştığı haber-i vahidle hüküm çıkarma konusunda ise İmam Şafii, haber-i vahidle amel etmenin dini açıdan bir sakınca doğurmayacağını belirterek, bu delile dayanmayan hiçbir tabiin aliminin bulunmadığını ifade eder. $\mathrm{Bu}$ kanaatini açıklarken şu çıkarımda bulunur. Örneğin adil iki şahidin söyledikleri ile mahkemede hüküm vermek nasıl mümkün oluyorsa, kendilerinde adalet dışında zabt gibi hafizayla ilgili şartların da arandığı bir-iki ravinin rivayet ettiği haberlerin de kabul edilmesi iktiza eder (Şafii, 1985: 46-47). 
Yalova Sosyal Bilimler Dergisi

İmam Şafii'nin kavl-i kadim olarak nitelendirilen Irak'daki görüşlerine örnek olarak şunları zikredebiliriz:

İmam Şafii'nin Hz. Peygamberden nakledilen altın ve gümüş kap kullanımımın yasaklanması hususundaki haber konusunda iki görüşü olduğunu görmekteyiz. Kadim görüşünde altın ve gümüşün kibre sebebiyet vermesi sebebiyle $\mathrm{Hz}$. Peygamber tarafından yasaklandığını ifade ederken, cedid görüşünde altın ve gümüşün mahiyeti itibariyle haram olduğunu ifade etmektedir. Bu farklılık hükmün illetinin de farklı olduğu sonucuna götürür ki; o da şayet kibir esas alınırsa hadiste zikri geçen maddeler dışındaki değerli taşlardan yapılmış kapları kullanmak da sakıncalı duruma düşmektedir. Ancak yeni görüşünde olduğu gibi mesele mahiyet itibariyle yoruma tabi tutulduğunda yasak yalnızca bu iki maddeyle sınırlı kalacaktır (Savluk, 2015: 65).

Yine kavl-i kadimde mest üzerine mesh etmenin hocası İmam Malik gibi süresiz olduğunu vurgularken kavl-i ceditte bunun yolcu için üç gün üç gece, mukim olan için ise bir gün ile sınırlı olduğu görüşünü beyan eder. Burada konuyla ilgili hadise yeni ulaşmış olması muhtemel gözükmektedir (Şasi, 1980, I: 130).

İbadetler bahsinde teyemmüm konusunda toprak yerine kum ile teyemmüm yapılabileceği kanaatine sahip iken (İ. Malik'in de bu görüşte olduğu zikredilir), kavl-i ceditte bunun geçerli olmadığını ifade etmiştir (Candan, 2011: 128).

Namaz kılacak olan kişiye bulaşan kanın miktarı ile ilgili olarak, kavl-i kadimde "örfen çok olmayan", "kişiyi rahatsız etmeyen" kanın, namaza mani olmadığını savunurken; kavl-i cedidte bit, pire gibi haşeratın bulaştırdığı kanların az, diğerlerinin ise çok olduğuna hükmederek bu durumun namaza mani olduğunu ifade etmiştir. İmam Şafii'nin birinci görüşüne mesned olarak örfü aldığını söylemek mümkündür. Buna karşılık kavl-i cedidte daha kuralcı bir yaklaşım sergilediği ifade edilebilir (Candan, 2011: 133).

İmam Şafii'nin kadim ve cedid olmak üzere görüşlerindeki değişimde örfün etkisi olmakla birlikte, verdiği fetvaların her biri için bu tespiti yapabilmek mümkün gözükmemektedir. Zira daha önce de ifade edildiği gibi mezhep imamlarının görüşlerindeki değişimin tek saikini örf veya coğrafi faktör olarak yorumlamak bizi yanıltacaktır. $\mathrm{Bu}$ değişimlerde şüphesiz alimin gün geçtikçe ilmi müktesabatının genişlemesinin yanında kendisine ulaşan hadis malzemesinin artması da önemli etkenler arasindadır.

\section{Hanbeli Ekolï}

Ahmet b. Hanbel 164 yılında bir rivayete göre Merv'de, bir rivayete göre Bağdat'ta dünyaya gelmiştir. Yaşadığı bölgedeki fikri ve siyasi hareketliliklerin kendi görüşlerinin oluşmasında etkili olduğu muhakkaktır. Dedesi Hanbel b. Hilal'in Emeviler devrinde Serahs valiliği yaptığı ve Abbasiler döneminde de önemli görevler üstlendiği bilinmektedir (Koca, 2002: 37).

Ahmet b. Hanbel'in hocaları arasında daha ziyade ehl-i hadis taraftarlarının ağırlıklı olduğu söylenebilir. Müsned'teki rivayetlere bakıldığında 280 adet hocadan ders aldığı anlaşılmaktadır. Bunların arasında Ebu Hanife'nin talebelerinden Ebu Yusuf'un da 
Yalova Sosyal Bilimler Dergisi

ismi zikredilmekle beraber, fikhi görüşlerinde Ebu Yusuf'un tesirinde kaldığını söylemek pek mümkün gözükmemektedir. ${ }^{11}$

Hadis ilmine yaptı̆ğ katkılarla anılan Ahmet b. Hanbel bütün ömrünü hadis toplamaya ve rivayet etmeye vakfetmiștir. Yaşadığı dönem coğrafya olarak ciddi siyasi ihtilafların ve kargaşaların vuku bulduğu bir dönemdi. Tarihte Mihne olayları olarak ifade edilen ve Abbasi halifesi Me'mun tarafindan başlatılan olaylarda, dönemin âlimlerinin siyasiler tarafindan derdest edilip sorguya çekildikleri bilinmektedir. Ahmet b. Hanbel de bu dönemde sorguya çekilen alimler arasında yer almıştır. Halife Me'mun başkadı Ahmet b. Ebu Duad'ın (ö. 240/854) da etkisiyle valilere gönderdiği talimatnamede Kur'an'ın yaratılmışlığı (Halku'I-Kur'an) konusunda alimleri sorguya çekmesini, ifade edilen görüşleri kendisine bildirmesini istemiştir. Ayrıca Kur'an'ın mahluk olduğunu benimsemeyenlere resmi görev verilmemesini ve şahitliklerinin kabul edilmemesini vurgular (Yücesoy, 2005, XXX: 26).

Söz konusu olaylarda Ahmet b. Hanbel'in dayatılan fikri kabul etmediği ve çeşitli işkencelere maruz kaldığı anlaşılmaktadır. Konuyla ilgi kendisinin görüşü şu cümleyle ifade edilir: "Kur'an Allah kelamıdır ve onun hakkında "mahluktur" demek küfür, "mahluk değildir" demek bid'attır (Ebu Yala, 1952, I: 62, 75).

Mezhep içerisindeki Hanbeli alimlerin farklı sıralamaları olsa da ittifak edilen kaynakları Kitap, Sünnet, İcma ve Istıshab olarak sayabiliriz. Şüphe yok ki fikıh usulünun en önemli konularından biri olan Istıshabın, Hanbelilerde başka bir delil bulunmadığında rey'e gitmek yerine eşyada asl olanın ibaha olması fikrini tercih ettikleri görülmektedir (Koca, 2002: 126 vd.). Öte yandan Ahmet b. Hanbel'in genel olarak sahabe veya tabiinden birden fazla görüş nakledilmişse, her birini kabulettiği, aralarında herhangi bir tercih yoluna gitmediği görülmektedir (Ebu Zehre, ty., II: 324). Ahmet $b$. Hanbel hayatında kendi fikhi görüşlerinin yazılmaması hususunda azami titizlik gösterdiğinden, ancak ölümünden sonra oğulları tarafindan kaleme alınan metinlerde görüşlerine rastlamaktayız. Zira O’na göre Kuran ve sünnetten başka hiçbir şey yazılmaya değer değildir. Her imamın kanaati kendi dönemini ve coğrafi bölgesini yansıttığından bu görüşleri ileriki zamanlara taşımakta herhangi bir fayda mülahaza etmemektedir (Ebu Zehre, ty., II: 292).

Ahmet b. Hanbel diğer üç ekolden farklı olarak görüşlerinin yazılmasına izin vermemesi sebebiyle hangi görüşünden rücu ettiği tam olarak tespit edilememektedir. Başka bir ifade ile mezhebin fikıh ve metodolojisinin vefatından sonra öğrencileri tarafından çeşitli görüş ve fetvaları temel alınarak kolektif bir çalışma şeklinde kaleme alınması, kimi zaman aynı konuda birbirine zıt görüşlerin de meydana gelmesine zemin hazırlamışırı (Koca, 2002: 211).

Kayıtlarda bulunan farklı görüşler hakkında Ebu Zehre şu kanaatini ifade etmektedir: "İmamın birbirine benzeyen konularda iki farklı görüşü bu durumun zaman ve şartlar bakımından farklılık sebebiyle olmuş olabileceğini ifade eder. Muhtemel ki birinci durumda dönemin şartları münasebetiyle verdiği fetvadan daha sonra vazgeçmiş

${ }^{11}$ Ahmet b. Hanbel'in hocalarının listesi için bkz. Zehebi, Ebû Abdullah Şemseddin Muhammed b. Ahmed b. Osman, (1982), Siyeru A'lâmi’n-Nübelâ (thk. Şuayb el-Arnaut), c. XI, Beyrut. 
Yalova Sosyal Bilimler Dergisi

olmalıdır. Her halükarda ikinci fetvanın yeni olup tercihe şayan olan görüş olduğunu belirtir. Öte yandan iki farklı görüşün tarihleri bilinemezse, iki faklı olay hakkında söylendiğini kabul etmek gerekir (Ebu Zehre, 1981: 204).

Ahmet b. Hanbel'in Müsned'ine zayıf hadisleri de aldığı bilinmektedir. Bu durumu oğluna açıklarken zayıf hadisin içeriğini reddeden başka bir rivayet yoksa onu da Müsned'ine aldığını ifade etmektedir (Ebu Zehre, 1981: 175). Özellikle eserin içeriği incelendiğinde yönetim, yönetici ve hilafet ile ilgili hadislerin diğer hadis eserlerine kıyasla daha büyük bir yekûn tuttuğunu ifade etmek mümkündür. Şüphe yok ki bunda dönemin siyasi gelişmelerinin etkisi inkar edilemez. Zira diğer ekol kurucularına bakıldığı zaman onların İbn Hanbel kadar siyasi baskıya maruz kaldıklarını söylemek mümkün değildir (Aertikbaev, 2013: 172).

Hanbeli ekolünde ihtilaf edilen deliller arasında bulunan Sedd-i Zeria deliline gerek Ahmet $b$. Hanbel gerekse mezhebin ileri gelen alimleri tarafindan sıkça başvurulduğu bilinmektedir. Ahmet $b$. Hanbel'in bu kapsamda verdiği fetvaya şu örnek verilebilir: Fitne ve fesad zamanında silah satışının haram olduğu görüşü aktarılır. Başka bir ifade ile kötülüğe sebebiyet verecek her türlü satış ve kira da bu kabilden sayılır. Aynı şekilde komşuların alışverişine engellemek için ucuz fiyatla mal satandan alış veriş yapmayı da hoş karşılamadığı zikredilir (Ebu Zehre, 1981: 334).

Bir diğer delil olan örfün hükümlere tesiri konusunda Hanbeli alimlerinden İbn Kayyım el-CevziyyeI'lam-ı Muvakkiin adlı eserinde şu ifadeleri kullanır:

“..... İşte F1kıh budur. İnsanlara örf, adet ve zaman farklılıklarını dikkate almadan, kitaplarda mevcut bulunan nakillerle fetva veren bir kimse, hem kendisi yanlişa düşer, hem de diğer insanları yanlışa düşürür. Bu şekilde hareket eden kişinin dine karşı işlediği cinayet, tıp kitaplarındaki mevcut bilgilerle yola çıkıp da bütün insanlığı tedaviye kalkan kimsenin cinayetinden daha büyük bir durumdur (İbn Kayyim, 1973, III: 78)."

Yukarıda da ifade edildiği üzere Hanbeli mezhebinde pek çok füru meselede birden fazla fikhi görüşün günümüze kadar ulaşmış olması örf ve geleneğin, coğrafi faktörün mezhep içerisindeki hükümlere ne ölçüde yansıdığını tam olarak tespit etmek konusunda bir kanaate varmayı güçleştirmektedir. Öte yandan akit serbestiyeti konusunda Hanbeli mezhebinin diğer ekollere nazaran kendi döneminde en geniş fetvalara sahip bir ekol olduğunu söylemek yanlış olmayacaktır. Örneğin Aile hukukunda nikah akdinde öne sürülen şartlar konusunda en geniş fetvalar Hanbeli mezhebine aittir. Nitekim Osmanlı dönemindeki Hukuk-1 Aile Kararnamesinde Hanbeli mezhebinin görüşlerine de yer verilmiştir.

İslam akit teorisinde bir malın fiyatının belirlenmeden satışı mümkün olmamasına rağmen Ahmet $b$. Hanbel böyle bir satışın geçerli olduğunu ifade etmektedir. $\mathrm{Bu}$ görüşünü de da malın fiyatının dönemin şartlarına göre piyasa tarafından belirlenebileceğini savunarak temellendirmektedir (Ebu Zehre, 1981: 353-354).

Hanbeli mezhebinin kronolojik olarak diğer üç ekolden sonra gelmesi, hal-i hazırda oluşmuş fikhı kültür ve metolojinin argümanlarını kullanarak kendi usulünü sistemleştirdiğini söylemek yanlış bir kanaat olmasa gerek. Zira Hanefi, Maliki ve Şafii 
Yalova Sosyal Bilimler Dergisi

fikhının o zamana kadar bir bakıma birbirinden etkileşim ve tevarüsle meydana getirdiği fikhî yapıyı, ehl-i hadis düşüncesi ile birleşerek Hanbeli mezhebinin ilk dönem alimlerinde görmek mümkündür. Şüphe yok ki bu durum ekolün fikıh tarihi açısından özgünlük tartışmalarını da beraberinde getirmiştir. ${ }^{12}$

\section{Sonuç}

Tarih sahnesinde uzun süre kalmış günümüzde de tabiileri tarafindan yaşatılan fikhi hukuk ekolleri şüphesiz bulundukları bölge ve dönemlere göre gelişim seyri göstermişlerdir. Bu gelişim gerek Hz. Peygamberden kendi dönemlerine kadar ulaşan sahih hadis malzemesinin oranıyla, gerekse yayıldıkları coğrafya ve kültürün ihtiyaç ve sorunlarının tespiti ve çözüme kavuşturulmasıyla şekillenmiştir.

Dört fikhi hukuk ekolünü incelediğimiz bu çalışmanın amacı, ekolün ileri gelen âlimlerinin verdikleri fetvalarda bulundukları coğrafya, kültür ve sosyal şartların etkilerinin ne ölçüde olduğunu gün yüzüne çıkarmaktı. Öncelikle şu tespiti yapmak yerinde olur ki, her mezhep bulunduğu coğrafyadaki ihtiyaçlara göre bir literatür oluşturmuştur. $\mathrm{Bu}$ durum hemen hemen her ekol için ifade edebileceğimiz bir gerçekliktir. Ancak gerek mezhep imamlarının gerekse mezhebin ileri gelen âlimlerinin serdettikleri görüşlerde, ya da zamanla değiştirdikleri kanaatlerinin tek saikinin bulundukları coğrafya ve kültür olduğu söylemek iddialı bir kanaat olacaktır.

Şüphe yok ki, İslam dininin ilkelerindeki kolaylık prensibinin Hz. Peygamberin uygulamalarında da kendini gösterdiğine şahit olmaktayız. Nitekim Hz. Peygamberin kendisine yöneltilen sorular karşısında muhatabın durumunu göz önüne alarak, kolaylık ve maslahat prensiplerini önceleyerek cevap verdiği görülmektedir. Bugün elimizde bulunan hadis külliyatı bunun örnekleriyle doludur. Nitekim asl olan dinin temel prensiplerine halel getirmeden dönemin sorunlarına çözüm üretebilmektedir. $\mathrm{Bu}$ vazifeyi layık-1 veçhiyle $\mathrm{Hz}$. Peygamberin yerine getirdiğinde şüphe yoktur. $\mathrm{Bu}$ kabilden fikıh ekollerinin ileri gelen âlimleri de kendi dönemlerinin şartlarına göre gerek toplumsal problemler karşısında, gerekse ferdi anlaşmazlıklarda kendi müktesebatları ve dönemin şartlarına göre gerekli çözümleri oluşturmuşlardır.

Fıkıh ekollerin kendi kaynaklarından tespit ettiğimiz söz konusu fetvalardaki değişimin bölgesel ihtiyaçlara göre şekillendiğini anladığımız örneklerin yanında, fetvayı veren âlime ulaşan sahih hadis malzemesinin kemmiyeti, zamanla fetvayı veren âlimin kendi müktesebatının gelişmesi ve ilmi olgunluğa ulaşmasını da etkenler arasında zikretmek gerekir. Öte yandan mezhep imamları veya ekolün ileri gelenleri tarafindan verilen ya da sonraki dönemlerde değiştirilen görüşlerin sebeplerini doğru bir şekilde tespit etmek ve bunu her bir ekol için ayrı ayrı ele almak, bir makale boyutunu aşan bir çalışma olduğu gün yüzüne çıkmıştır. Elinizdeki bu makalenin ileride bu alanda yapılacak olan çalışmalara bir örneklik teşkil etmesini ve faydadan hali olmadığını ümid etmekteyim.

Son tahlilde coğrafya, kültür ve sosyal şartların oluşmuş fikhi ekoller üzerindeki etkisini tespit etmeye çalıştığımız bu makalede, İslam fikhındaki örfün hükümler

12 Geniş bilgi için bkz. Özmen, Ramazan, (2008), "Doğuştan Tedvinine Hanbeli Fıkıh Usulü Geleneği ve Özgünlük Sorunu”, İslam Hukuku Araştırmaları Dergisi, sy.11, s.189-216. 
Yalova Sosyal Bilimler Dergisi

üzerindeki tesirini göz ardı etmemekle birlikte, meydana gelen ekollerde tek sebebin zikredilen etkenler olduğunu savunmak akademik yaklaşımdan uzak bir yorum olacaktır. Şüphe yok ki söz konusu ekoller tarafindan bugüne kadar oluşturulmuş fikhi gelenek ve literatür dönemin şartlarında önemli bir boşluğu doldurmuş, ihtiyaç ve problemlere çözüm üretmiştir. Öte yandan bu konuda anakronizme düşmeden, her fikhî birikim ve literatürü kendi şartları içerisinde değerlendirerek, yüzyıl sonra oluşmuş çözüm bekleyen problemlerin çözümlerini, söz konusu fikhî ekollerin oluştuğu döneminin gelenekleri içerisinde aramak, İslam'ın gerek evrensellik ilkesi, gerekse içtihad prensibiyle örtüşmeyeceği aşikârdır.

\section{Kaynakça}

Aertikbaev, Kudrat, (2013), “Ahmet b. Hanbel'in Müsned'i Üzerine Yorumlar”, Iğdır Üniversitesi İlahiyat Fakültesi Dergisi, Ekim, sy. 2, s. 165-178.

Aktepe, İshak Emin, (2008), Erken Dönem İslâm Hukukçularının Sünnet Anlayışı, İstanbul.

Aybakan, Bilal, (2011), İmam Şafii ve Fıkıh Düşüncesinin Mezhepleşmesi, İstanbul.

Aybakan, Bilal, (2003), Fıkıh İlminin Oluşum Sürecinde İcma, İstanbul.

Aybakan, Bilal, (2010), “Şafii”, DíA, İstanbul, c. XXXIIX, s. 223-233.

Bedir, Murteza, Buhara Hukuk Okulu, İstanbul 2014.

Candan, Abdurrahman, (2011), “İmam Şafii’nin Erken Dönem Görüşlerinin Oluşmasında İmam Malik'in Etkisi”, Diyanet İlmi Dergi, Nisan-Mayıs-Haziran, c. 47, sy. 2, s. 117-144.

Ebu Yala, Kadı Ebu Hüseyin Muhammed, (1952), Tabakatü'l-Hanabile, Beyrut, c. I.

Ebu Zehre, (1948), eş-Şafii Hayatuhu ve Asruhu Arauhu ve Fıhkuku, Kahire.

Ebu Zehre, (1981) İbn Hanbel Hayatühu ve Asrühu-Araühu ve Fıkhuhu, Kahire.

Ebu Zehre, (ty.), Tarihu'l-Mezahibi'l-İslamiyye, Kahire, c. II.

Faruq1, Muhammed Y., (1992) "Consideration of 'Urf in theJudgments of theKhulefâ' al Râshidun and the Early Fukahâ" The American Journal of Islamic Social Sciences, Volume 9, number 4, p. 482-498.

Fullani, Salih b. Muhammed b. Nuh b. Abdullah b. Ömer b. Musa Ömerî, (ty.), İkazu'l-Himem Ulu'l-Ebsâr, Cidde.

Güllük, İsmail, (2003), Ebu'l-Leys Semerkandi'nin Nevazil'i Ișığında Sosyal Olgu ve Fetva İlişkisi, Marmara Üniversitesi Sosyal Bilimler Enstitüsü, Yüksek Lisans Tezi, İstanbul.

İbn Abidin, Muhammed Emin b. Ömer b. Abdülaziz ed-Dımaşki, (ty.), "Neşru'l- Urffi binâ-i bazi'lAhkam-ı'l-Urf”, MecmuatuResailiíbn Abidin, c. II, s. 112-145.

İbn Haldun, Ebu ZeydVeliyüddin Abdurrahman b. Muhammed, (1982), Mukaddimetü’l-Allame İbn Haldun, Beyrut.

İbn Kayyım el-Cevziyye, Ebû Abdullah Şemseddin Muhammed, (1973), İlâmu'l-Muvakkın an Rabbi'l-Âlemin, Beyrut, c. III.

İbnRüşd, Ebu'l-Velid Muhammed b. Ahmet b. Muhammed Kurtubi, (1997) Bidayetül-Müçtehid ve Nihayetü'l-Muktesid(thk. Abdülmecid Tu'me Halebi), Beyrut, c. I, III.

İnanır, Ahmet, (2015), “İbnEbi’l-İzz el-Hanefi ve Muhammed b. Ali es-Senûsî Örneğinde Kuzey Afrika'da İctihad Hareketleri”, Çukurova Üniversitesi İlahiyat Fakültesi Dergisi, c. XV, sy.1, s. 149-175. 
Yalova Sosyal Bilimler Dergisi

İnanır, Ahmet, (2013), “İbnEbi'l-İzz'in 'Ittiba’ Adli Risalesi Bağlamında Ebu Hanife ve Hanefi Mezhebi Örneğinde Taklide Dair Görüşleri” Gaziosmanpaşa Üniversitesi İlahiyat Fakültesi Dergisi, 2013, c. I, sy. 2, s. 225-260.

Kadı Abdülvehhab, Ebû Muhammed Abdülvehhabb. Ali b. Nasr Bağdadi, (1999), el-İşraf ala Nüketi Mesaili'l-Hilaf, Beyrut, c. II.

Kadıhan, Ebü'l-Mehasin Fahreddin Hasan b. Mansur b. Mahmûd, (1865), FetavaKadihan, Kahire, c. I.

Karafi, Ebu'l-Abbas Şehabettin Ahmed b. İdris b. Abdurrahim (1993), ŞerhuTenkîhi'l-Füsûl, Kahire.

Kasani, Ebu Bekr Alaeddin Ebu Bekr b. Mesud b. Ahmed el-Hanefi, (1997), Bedaiü's-Sanai fi

Tertibi'ş-Şeria, (thk. Ali Muhammed Muavvaz, Adil Ahmed Abdülmevcut) Beyrut, c. VIII.

Kaya, Eyüp Said, (2003), “Maliki Mezhebi”, Ankara, DİA, c. XXVII, s. 519-535.

Kayapınar, Hüseyin, (2006), “Müzaraa”,DİA, İstanbul, c. XXXII, s. 234-236.

Kevseri, Muhammed Zahid b. Hasan b. Ali Zahid, (1952), Bulugu'l-Eman fi Siretï'l-İmam Mumammed b. El- Hasan eş-Şeybani, Kahire.

Kızılkaya, Necmettin, (2016), İslam Hukukunda Farklar, İstanbul.

Koca, Ferhat, (2002), İslam Hukuk Tarihinde Selefi Söylem, Hanbeli Mezhebi, Ankara.

Malik b. Enes, (1994), Muvatta, (trc. Ahmet M. Büyükçınar, Vecdi Akyüz), c. III.

Matlub, Mahmud, (1972), Ebu Yusuf Hayâtuhu ve Asâruhu ve Arâuhu'l-Fıkhıyye, Bağdat.

Öğüt, Salim, (1994), “Ebu Yusuf”, DİA, X, 260-265.

Özmen, Ramazan, (2008), “Doğuştan Tedvinine Hanbeli Fıkıh Usulü Geleneği ve Özgünlük Sorunu”, İslam Hukuku Araştırmaları Dergisi, sy.11, s.189-216.

Rıza, M. Reşid (1974), İslam'da Birlik ve Fıkıh Mezhepleri (trc. A. Hamdi Akseki, Sadeleştirme Hayrettin Karaman) Ankara.

Safedi, Ebli's-Safa Selahaddin Halil b. Aybek, (1974), el-Vafibi'l-Vefeyat, Wiesbaden, c. II.

Savluk, Hikmet, (2015), “İmam Şafii’nin Bir Meselede İki Görüşü Olması Sorunu (es-Silsile Örneği)",'IHYA Uluslararası İslam Araştırmaları Dergisi, c. 1, sy. 2, s. 57-82.

Sıbâi, Mustafa, (1978), es-Sünne ve Mekânetuhafi’t-Teşrî’l-İ́slami, Dımaşk.

Şafii, (1985), İhtilafu'l-Hadis (thk. Amir Ahmed Haydar), Beyrut.

Şafii, Ebu Abdullah Muhammed b. İdris b. Abbas, (1968), el-Umm, Kahire, c. II, VII

Şasi, Ebu Bekr Muhammed b. Ahmed Kaffal, (1980), Hilyetü'l-Ulema fi Ma'rifet-i Mezahibi’lFukaha (thk. Yasin Ahmed İbrahim Deradeke, Beyrut.

Taş, Aydın, (1994), “Şeybani, Muhammed b. Hasan”, DİA, İstanbul, c. XXXIX, s. 38-42.

Tetik, Hasan, (2006), Kadıhan'ın El-Fetava Adı Eserinde Örf ve Adet, Marmara Üniversitesi Sosyal Bilimler Enstitüsü Yüksek Lisans Tezi, İstanbul.

Yılmaz, Osman, (2008), Endülüs Mâliki Hukuk Geleneğinde Mezhep İçi İstidlal Yöntemi Olarak Mâ Cerâ Bihi'l-Amel Kavramı, Sakarya Üniversitesi Sosyal Bilimler Enstitüsü Yüksek Lisans Tezi.

Yücesoy, Hayrettin, (2005), “Mihne”,Di̇A, İstanbul, c. XXX, s. 26-28.

Zehebi, Ebû Abdullah Şemseddin Muhammed b. Ahmed b. Osman, (1982), Siyer-u A'lâmi'nNübelâ (thk. Şuayb el-Arnaut), c. XI, Beyrut.

Zeydan, Abdülkerim, (1982), el-Medhal li-Dirâseti’ş-Şeriati’l-İslamiyye, Bağdat. 